DOI 10.15290/cnisk.2021.01.10.11

\author{
ANNA SZWED-WALCZAK \\ https://orcid.org/0000-0002-9878-1401 \\ Uniwersytet Marii Curie-Skłodowskiej w Lublinie
}

\title{
Wywiad prasowy w polskiej prasie dla kobiet (w latach 1989-1992) - źródło wiedzy o życiu kobiet w czasie transformacji systemowej ${ }^{1}$
}

\begin{abstract}
Streszczenie
Wywiad prasowy jest nie tylko jednym $z$ ważniejszych gatunków dziennikarskich, lecz także źródłem wiedzy o życiu w danym okresie historycznym. Badania wywiadów prasowych pozwalaja bowiem na ustalenie spraw w danym czasie istotnych dla adresatów pisma. Celem badań była rekonstrukcja medialnego obrazu życia kobiet w latach 1989-1992 na łamach polskiej prasy dla kobiet. W toku procedury badawczej zwrócono uwagę na: dominująca tematykę poruszaną w wywiadach, obraz transformacji ustrojowej, płeć interlokutorów oraz ich kompetencje zawodowe (w jakim charakterze występowali w wywiadzie). Badanie objęło 208 numerów tygodnika „Kobiety i Życia” oraz 208 numerów tygodnika „Przyjaciółka”, których nakład wynosił ponad 500 tys. egzemplarzy. Dokonano również kategoryzacji wywiadów opublikowanych w tygodnikach do szeroko rozumianej sfery społecznej, politycznej i gospodarczej. Wyselekcjonowano te wywiady, których temat przewodni stanowiły konsekwencje transformacji systemowej. W „Kobiecie i Życiu” były to 42 wywiady, w „Przyjaciółce” -

Publikacja przygotowana/finansowana w ramach programu Ministra Nauki i Szkolnictwa Wyższego pod nazwa DIALOG w latach 2019-2021. Jest wynikiem udziału w projekcie badawczym pt. „Ośrodek badań historii kobiet”, nr 0016/DLG/2019/10.
\end{abstract}


było ich 77 . Jakościowa analiza treści pozwoliła na pogrupowanie tematyki wywiadów na sześć kategorii: gospodarka, polityka, pomoc społeczna, edukacja, służba zdrowia, prawo.

Słowa kluczowe: Prasa dla kobiet, wywiad prasowy, transformacja systemowa w Polsce, życie kobiet polskich, „Kobieta i Życie”, „Przyjaciółka”, Polska 1989-1992

\title{
PRESS INTERVIEW \\ IN THE POLISH WOMEN'S PRESS (1989-1992) - A SOURCE OF KNOWLEDGE ABOUT WOMEN'S LIVES DURING THE SYSTEM TRANSFORMATION
}

\begin{abstract}
The press interview is one of more important journalistic genres and a source of knowledge about life in a given historical period. Research on press interviews makes it possible to determine matters relevant to the magazine's addressees at a given time. The aim of the research was to reconstruct the media image of women's life in 1989-1992 in the Polish women's press. During the research procedure, attention was paid to: the dominant topics covered in the interviews, the picture of systemic transformation, the gender of interlocutors and their professional competences. The research covered 208 issues of the weekly Kobieta $i$ Życie [Woman and Life] and 208 issues of the weekly Przyjaciótka [Best Friend]. The selection of magazines was dictated by their high circulation (over 500,000 copies). The interviews published in weekly magazines was categorized into the broadly understood social, political and economic sphere. In Kobieta i Życie it was 42 interviews, in Przyjaciółka - 77. The qualitative analysis of the content allowed to group the topics of interviews into six categories: economy, politics, social assistance, education, healthcare and law.

Keywords: women's press, press interview, system transformation in Poland, life of Polish women, Kobieta $i$ Życie [Woman and Life], Przyjaciółka [Best Friend], Poland 1989-1992
\end{abstract}

\section{Uwagi wstępne}

Wywiad prasowy jest jednym $z$ ważniejszych gatunków dziennikarskich ${ }^{2}$. Magdalena Ślawska uważa, że jego popularność

2 Badacze jego geneze dostrzegaja w dialogach platońskich, traktatach i pismach filozoficznych, artykułach politycznych i drukach ulotnych pisanych w formie pytań i odpowiedzi. 
i atrakacyjność wynika $z$ tego, że „sprawia on wrażenie niezafałszowanego, autentycznego, bezpośredniego kontaktu $z$ informacjami, opiniami ludzi będących bohaterami wywiadów"3. Badacze wskazują, że może pełnić funkcje perswazyjna, promocyjną (przyciaga czytelników), poznawczą ${ }^{4}$. Charakteryzuje się określoną strukturą: formą dialogową złożoną z pytań i odpowiedzi, ich naprzemiennościa, co najmniej dwoma uczestnikami $z$ jasno określonymi rolami (prowadzącego wywiad dziennikarza oraz uczestnika-rozmówcę, znawcę tematu), dostosowaniem języka i stylistyki do adresatów (miejsca publikacji wywiadu) ${ }^{5}$. W zależności od roli, jaka przyjmie dziennikarz, można zaklasyfikować go do gatunku informacyjnego lub publicystycznego. Najczęściej jest jednak nazywany gatunkiem synkretycznym lub pogranicznym. Może funkcjonować samodzielnie lub występować w różnych gatunkach dziennikarskich. Stanowi ważne źródło pozyskiwania informacji, ale też kształtowania opinii ${ }^{6}$. Wywiad prasowy jest również istotnym źródłem wykorzystywanym $\mathrm{w}$ badaniu wydarzeń historycznych. Pozwala bowiem zrekonstruować medialny obraz świata w danym okresie ${ }^{7}$. Zwraca uwagę na ważkie problemy czytelników pisma (przez tematykę, której dotyczy, oraz poprzez dobór rozmówców). Należy do „źródeł pośrednich adresowanych”, zawiera określona interpretację i jest

Za pierwszy wywiad prasowy jako gatunek dziennikarski uznaje się $z$ kolei wywiad Jamesa Gordona Bennetta, którego rozmówcą był poczmistrz z Buffalo. Wywiad został opublikowany 13.10.1835 r. w „New York Herald”. Zbigniew Bauer, „Wywiad prasowy. Gatunek i metoda”, w: Zbigniew Bauer, Edward Chudziński (red.), Dziennikarstwo $i$ świat mediów, (Kraków: Universitas, 2004), 188; Maria Wojtak, Gatunki prasowe, (Lublin: Wydawnictwo UMCS, 2004), 239.

3 Magdalena Ślawska, Formy dialogu w gatunkach prasowych, (Katowice: Wydawnictwo Uniwersytetu Ślaskiego, 2014), 70.

4 Małgorzata Kita, Wywiad prasowy. Języ - gatunek - interakcja, (Katowice: Wydawnictwo Uniwersytetu Ślaskiego, 1998), 167-168; Piotr Lewandowski, Creative writing publicystycznych tekstów dziennikarskich. Kreatywny wywiad dziennikarski, (e-bookowo.pl, 2005), 128.

5 Piotr Lewandowski, Creative writing, 138-139; zob. Barbara Daleszak-Wajdzik, „Rozważania o wywiadzie prasowym", Zeszyty Prasoznawcze, nr 1, 1974, 38-40.

6 Zbigniew Bauer, „Wywiad prasowy. Gatunek i metoda”, 186-188; Kazimierz Wolny-Zmorzyński, Andrzej Kozieł, „Genologia dziennikarska”, Studia Medioznawcze, nr 3, 2013, 30; Kazimierz Wolny-Zmorzyński, Andrzej Kaliszewski, Wojciech Furman, Gatunki dziennikarskie: teoria, praktyka, jezzk, (Warszawa: Wydawnictwa Akademickie i Profesjonalne, 2009), 34; Piotr Lewandowski, Creative writing, 127.

7 Należy pamiętać, że medialny obraz świata nie stanowi wiernego odzwierciedlenia rzeczywistości. Jak zaznaczył Walery Pisarek, „Obraz zawsze upraszcza i zubaża rzeczywistość: odbija tylko niektóre ze składających się na nią przedmiotów, tylko niektóre ich cechy, tylko niektóre relacje między nimi i tylko niektóre sposoby ich ruchu lub zmiany", Walery Pisarek, O mediach i języku, (Kraków: Universitas, 2007), 62. 
skierowany do znanej dziennikarzowi publiczności ${ }^{8}$. Można sformułować tezę, że wywiad prasowy $z$ jednej strony jest wykreowany przez potrzeby czytelników $\mathrm{w}$ zakresie uzupełnienia wiedzy $\mathrm{w}$ danym temacie, $z$ drugiej zaś jest pochodna linii programowej redakcji, a więc narzucenia czytelnikowi tematyki rozważań. Jak zauważył Igor Borkowski, wybór tematyki wywiadu zazwyczaj uwarunkowany jest ważnym wydarzeniem, co do którego istnieje potrzeba refleksji i wyjaśnienia go przez specjalistę, ale też temat może być narzucony przez redakcję ${ }^{9}$.

Celem badań była rekonstrukcja medialnego obrazu życia kobiet w czasie pierwszego etapu transformacji systemowej w Polsce. Należy zaznaczyć, za Grzegorzem Ptaszkiem, że medialny obraz otaczającego świata jest tworzony dla określonego czytelnika ${ }^{10}$, w przypadku tych badań - dla kobiet. Ciekawość badawcza wzbudzał sposób, w jaki prasa dla kobiet ukazywała w wywiadach skutki transformacji systemowej dla życia politycznego, społecznego oraz gospodarczego. Założono bowiem, że prasa za pomoca wywiadów $z$ autorytetami dażyła do zmiany postaw czytelniczek wobec przemian.

Za zasadne uznano zweryfikowanie: 1 ) dominujacej tematyki poruszanej w wywiadach, w tym też charakter ${ }^{11}$ wywiadu - a więc odnoszac się do klasyfikacji Hansa J. Netzera, czy jest on informacyjny i dotyczy faktów (zur Sache), czy ukazuje postać, z która rozmawia dziennikarz (zur Person) ${ }^{12}$; 2) obrazu transformacji, który wyłania się $z$ wywiadu; 3) frekwencyjności płci interlokutorów oraz 4) ich kompetencji (doświadczenie zawodowe oraz kwalifikacje).

Cezura początkowa był rok, w którym w wyniku obrad Okragłego Stołu zainicjowano transformację systemowa. Badania zakończono na roku 1992, w którym to Sejm I kadencji uchwalił tzw.

\footnotetext{
8 Izabela Lewandowska, „Wywiad jako technika zdobywania informacji źródłowych w badaniu historii najnowszej”, Echa Przeszłości, nr 5, 2004, 281-282.

9 Igor Borkowski, „Współczesny prasowy wywiad dziennikarski: techniki prowadzenia, opracowanie, publikacja”, Wrocławski Rocznik Historii Mówionej, nr 1, 2011, 60-61.

10 Grzegorz Ptaszek, „Jak badać medialny obraz świata?”, w: Iwona Hofman, Danuta Kępa-Figura (red.), Współczesne media. Medialny obraz świata, t. 1: Zagadnienia teoretyczne, (Lublin: Wydawnictwo UMCS, 2015), 17.

11 Sally Adams oraz Wynford Hicks wskazali, że nie można opisywać wywiadu jako celowej rozmowy, "chyba że mamy na myśli mądrze sterowaną i raczej jednostronną rozmowę”, zob. Sally Adams, Wynford Hicks, Wywiad dziennikarski, tłum. Katarzyna Franek, (Kraków: Wydawnictwo UJ, 2007), 41.

12 Zbigniew Bauer, „Wywiad prasowy. Gatunek i metoda”, 190.
} 
mała konstytucję ${ }^{13}$. Przedmiotem zainteresowania były tygodniki, które osiagały w badanym okresie największy nakład (powyżej 500 tys. egzemplarzy): „Kobieta i Życie” oraz „Przyjaciółka” ${ }^{14}$. Oba pisma miały ugruntowana pozycję na polskim rynku prasowym, a także określonego adresata. Czytelniczkami „Przyjaciółki” były głównie mieszkanki wsi i małych miasteczek (środowisko chłopskie i robotnicze), natomiast adresatkami „Kobiety i Życia” - kobiety zamieszkałe w mieście, aktywne w życiu zawodowym i społecznym, co nie oznaczało, że pisma nie trafiały do innych grup odbiorców.

Badanie objęło 208 numerów tygodnika „Kobiety i Życia” oraz 208 numerów tygodnika „Przyjaciółka” (przebadano wszystkie numery, które ukazały się w latach 1989-1992). Dokonano również kategoryzacji wywiadów opublikowanych w tygodnikach do szeroko rozumianej sfery społecznej, politycznej i gospodarczej. Wyselekcjonowano te wywiady, których tematem przewodnim były konsekwencje transformacji systemowej ${ }^{15}$. W „Kobiecie i Życiu” były to 42 wywiady, w „Przyjaciółce” ukazało się takich 77 . Odrzucono wywiady o tematyce lifestylowej, poradnikowej, plotkarskiej. W toku gromadzenia materiału badawczego zdecydowano o pominięciu $\mathrm{w}$ badaniach nieklasycznych form wywiadu, tj. ankiet, sond dziennikarskich, dyskusji - wypowiedzi notowanych przez dziennikarzy. Spowodowane było to ograniczonymi możliwościami dziennikarza do kreowania „atmosfery” pozyskiwania informacji oraz brakiem możliwości zadawania pytań uszczegółowiających. W badaniach zdecydowano się na połączenie metody analizy zawartości prasy

\footnotetext{
13 Ustawa konstytucyjna $z$ dnia 17 października 1992 r. o wzajemnych stosunkach między władzą ustawodawczą i wykonawczą Rzeczypospolitej Polskiej oraz o samorządzie terytorialnym, Dz.U. 1992 Nr 84, poz. 426.

14 W 1989 r. funkcjonowało 16 czasopism dla kobiet. Były to tygodniki, miesięczniki, kwartalniki oraz roczniki. Różnicował je nakład, poruszana tematyka, dominujące funkcje. Zofia Sokół, „Transformacja czasopism kobiecych w Polsce (1989-1997)”, Rocznik Historii Prasy Polskiej, t. 1, z. 1-2, 1998, 193-201; por. Ryszard Filas, „Zmiany w czytelnictwie prasy w Polsce 1989-1992 na tle przemian oferty prasowej”, w: Alina Słomkowska (red.), Transformacja prasy polskiej (1989-1992), (Warszawa: Dom Wydawniczy Elipsa,1992), 36.

15 Posiłkujac się klasyfikacja wywiadu B. Sobczak, przedmiotem badań objęto wywiady polityczne, ale też informacyjne. Pierwsze charakteryzowały się poruszaniem tematyki gospodarczej, politycznej, ale też aktualnej i wyczekiwanej przez odbiorców pisma. W wywiadzie informacyjnym rozmówca był specjalista, znawca tematu, uczestnik wydarzenia, posiadający kierunkowe wykształcenie oraz doświadczenie zawodowe w dziedzinie, o której się wypowiada. Barbara Sobczak, Wywiad telewizyjny na żywo. Charakterystyka gatunku, (Poznań: Wyd. „Poznańskie Studia Polonistyczne”, 2006), 36; Piotr Lewandowski, Creative writing, 128.
} 
i analizy treści ${ }^{16}$. Ważne było, aby wyszczególnić kategorie tematyczne poruszane w wywiadach, a także ustalić ich frekwencyjność. Jak zauważył medioznawca Denis McQuail, połączenie metody ilościowej z jakościowa (interpretacyjna) pozwala na wskazanie nie tylko proporcji materiałów na określone tematy, ale też na odkrycie struktury znaczeń dominujących ${ }^{17} \mathrm{w}$ medium. Za Walerym Pisarkiem należy jednak zaznaczyć, że:

Analiza zawartości prasy nie odkrywa świata rzeczywistego. Badajac przekazy prasowe, ujawniamy jednak jego obraz ukształtowany świadomie lub podświadomie przez kolektywnego nadawcę, a rekonstruowany faktycznie lub potencjalnie przez odbiorców właściwie lub niewłaściwie, zgodnie lub niezgodnie $z$ intencja nadawców ${ }^{18}$.

\section{Tematyka wywiadów opublikowanych na lamach badanych pism}

Jak wskazano w uwagach wstępnych, przedmiotem zainteresowania były wywiady, które ukazywały skutki transformacji systemowej. Biorac pod uwage ten wyznacznik, wyselekcjonowano łącznie 119 wywiadów (42 w „Kobiecie i Życiu”, 77 w „Przyjaciółce”). Jakościowa analiza treści pozwoliła na pogrupowanie ich na sześć kategorii: gospodarka, polityka, pomoc społeczna, edukacja, służba zdrowia, prawo. Pierwsza kategoria zawierała diagnozę gospodarki, opis oraz ocenę wdrażanych i planowanych reform. Często motywem dominującym było bezrobocie. Do tematyki politycznej zaklasyfikowano wywiady, w których oceniano aktywność polityków i organizacji o charakterze politycznym, ale też ich przedsięwzięcia, inicjatywy ustawodawcze. Szczególną atencję redakcji wzbudziły sprawy bezpośrednio dotyczące kobiet, w tym kwestia równouprawnienia. Trzecią kategoria tematyczna obecną w wywiadach była pomoc społeczna: zasiłki, alimenty, bony żywieniowe. Następna - edukacja przedszkolna oraz szkolna. Stanowiły one drażliwą kwestię $z$ uwagi na kryzys szkolnictwa polskiego w trakcie

16 Zob. J.K. [Jacek Kołodziej], „Analiza zawartości mediów”, w: Walery Pisarek (red.), Słownik terminologii medialnej, (Kraków: Universitas, 2006), 6-8.

17 Denis McQuail, Teoria komunikowania masowego, thum. Marta Bucholc, Alina Szulżycka, (Warszawa: Wydawnictwo Naukowe PWN, 2008), 361-362.

18 Walery Pisarek, O mediach i języku, 62. 
transformacji. Związane było to $z$ brakiem funduszy na dofinansowanie żywienia dzieci oraz utrzymanie świetlic. Piątą kategorią była służba zdrowia i problemy związane $z$ zaopatrzeniem aptek w leki. Ostatnią kategorią wyszczególnioną w toku analizy było zmieniające się prawo.

Zauważyć można, że proporcje udziału poszczególnych kategorii tematycznych były różne w obu tygodnikach. Zmienną różnicująca zawartość wywiadu był adresat pisma (zob. wykres nr 1).

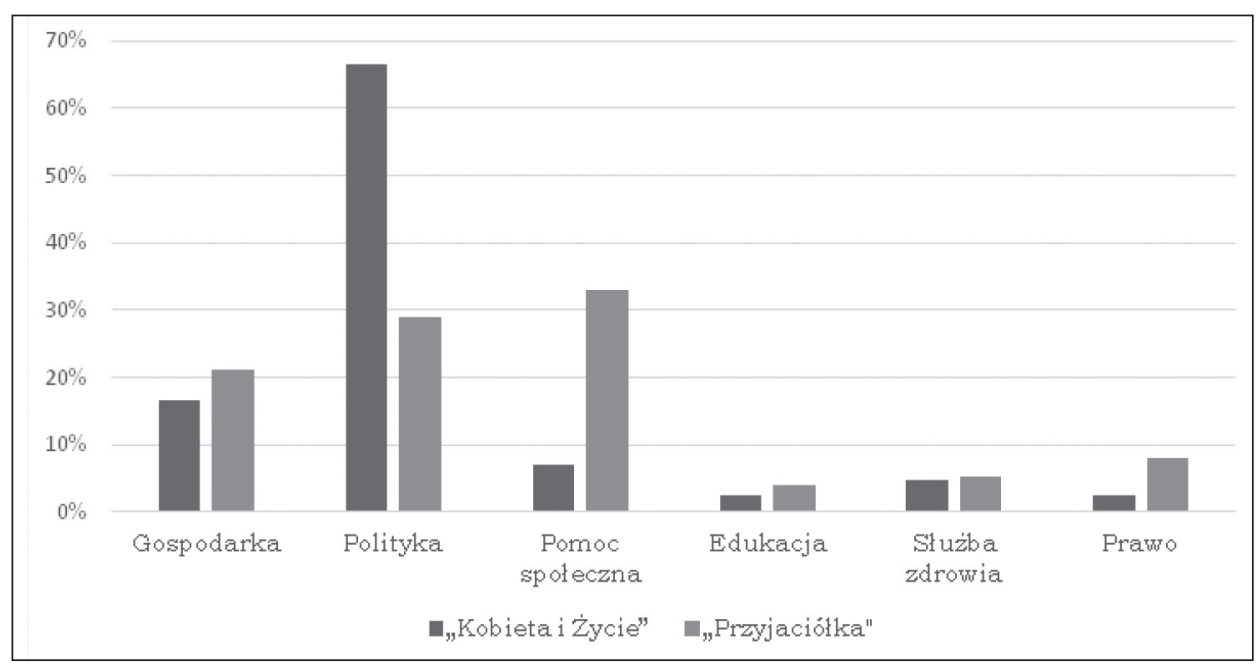

Wykres nr 1. Udział kategorii tematycznych w wywiadach na łamach badanej prasy Źródło: Opracowane na podstawie własnych badań.

W obu tygodnikach znaczaca tematyka była gospodarka. Częściej omawiano ja w wywiadach dla „Przyjaciółki” („Kobieta i Życie” - 16,67\%, „Przyjaciółka” - 21,05\%). We wspomnianym piśmie informowano głównie o drastycznych skutkach reform, ale też publikowano porady, jak wyjść z kryzysowej sytuacji. Z kolei w wywiadach tygodnika „Kobieta i Życie” reformy gospodarcze prezentowano nie poprzez pryzmat ich teraźniejszych skutków, lecz w perspektywie szansy na lepsza przyszłość. Informowano czytelników o przebiegu reform i planach ustawowych ${ }^{19}$. Reformy ukazywano

\footnotetext{
19 Rozmowa Natalii Iwaszkiewicz z posłem na Sejm dr. Marcinem Święcickim: „Weksel do wykupienia”, Kobieta i Życie (dalej: KiŻ), nr 32, 23.08.1989, 2.
} 
jednak jako niezbędne do modernizacji gospodarki ${ }^{20}$. W „Przyjaciółce", która trafiała też do mieszkanek wsi, podejmowano dodatkowo wątek rolnictwa. O ile w 1989 r. zwracano uwagę na brak sprzętu rolniczego i środków ochrony roślin, które pozwoliłyby na urynkowienie rolnictwa ${ }^{21}$, to $\mathrm{w} 1991 \mathrm{r}$. ukazywano rolnictwo jako podstawowa dziedzinę polskiej gospodarki, która może przyspieszyć rozwój gospodarczy ${ }^{22}$. Tym samym dowartościowywano ten sektor gospodarki oraz mieszkańców wsi, wskazując na ich wkład w poprawę życia Polaków.

Kwestia polityki pojawiła się w $66,67 \%$ wywiadów „Kobiety i Życia" ( $z$ czego ponad połowa $z$ tej kategorii dotyczyła równości płci). Nie oznacza to, że tej problematyki nie podejmowano w „Przyjaciółce” $(28,95 \%$ zawartości wywiadów). W obu tygodnikach zaprezentowano wywiad z prof. Anna Przecławska, jedyna kobieta uczestniczaca $w$ inauguracji obrad Okragłego Stołu. W wywiadach obrady Okragłego Stołu przedstawiano jako „absolutna konieczność” oraz „koło ratunkowe”23, z tym że ideę demokracji, społeczeństwa obywatelskiego rozpatrywano wyłącznie w wywiadach zamieszczonych w tygodniku „Kobieta i Życie”"24. Poza prezentacją pozytywnych skutków zmian politycznych ${ }^{25}$, zauważa-

20 Rozmowa Grażyny Wróblewskiej z prof. Januszem Szoslandem, prezesem Stowarzyszenia Włókienników Polskich: „Ministrowie odchodzą - problemy pozostają, KiŻ, nr 36, 20.09.1989, 2-3; Rozmowa Grażyny Musiałek z Wiesławą Ziółkowską, posłanką na Sejm: „Reguła wahadła”, KiŻ, nr 47, 6.12.1989, 2-3; Rozmowa Grażyny Wróblewskiej z dr. Ryszardem Bugajem, ekonomista, posłem na Sejm: „Punkt ryzyka”, Ki்̇, nr 49, 20.12.1989, 4-5; Rozmowa Grażyny Wróblewskiej z dr. Ryszardem Bugajem, posłem na Sejm: „Czyim kosztem?”, KiŻ, nr 20, 15.05.1991, 2-3; Rozmowa Marii Mankiewicz z Grzegorzem Mędza, wicedyrektorem Departamentu Przekształceń Własnościowych Wielkich Przedsiębiorstw w Ministerstwie Przekształceń Własnościowych: „Chcesz mieć akcje...”, KiŻ, nr 29, 17.07.1991, 3.

21 Rozmowa Kaliny Dastych z Kazimierzem Olesiakiem, wicepremierem, ministrem rolnictwa, leśnictwa i gospodarki żywnościowej: „Z tej mąki będzie dobry chleb”, Przyjaciótka (dalej: Prz), nr 19, 11.05.1989, 3.

22 Rozmowa Elżbiety Banasiak z Gabrielem Janowskim, senatorem, przewodniczącym „Solidarności” Rolników Indywidualnych: „Dziś o kondycji rolników”, Prz, nr 16, 18.04.1991, 2; Rozmowa Wiesławy Piątek z dr. inż. Bolesławem Woźniakiem, prezesem Agencji Rynku Rolnego: „Dziś o tym, czy urodzaj będzie klęska”, Prz, nr 33, 15.08.1991, 2.

23 Rozmowa Danuty Bierzańskiej z prof. Anną Przecławską: „Koło Ratunkowe”, Ki்̇, nr 9, 1.03.1989, 4-5; por. Rozmowa Zygmunta Włoczewskiego z prof. Anną Przecławską: „Popieram filozofię Zagłoby", Prz, nr 14, 6.04.1989, 5.

24 Rozmowa Danuty Bierzańskiej z dr Danutą Waniek: „Niebezpieczna nieobecność”, KIŻ, nr 45, 22.11.1989, 5.

25 Rozmowa Krystyny Kaszuby z Lidia Smyczyńską, redaktor naczelna „Tygodnika Demokratycznego”: „Gdy jest się mała partia”, Ki், nr 18, 3.05.1989, 4; Rozmowa Natalii Iwaszkiewicz z Barbara Malak, rzecznikiem prasowym Komisji Krajowej NSZZ „Solidarność”, KiŻ, nr 33, 15.08.1990, 2-3. 
no, że w trakcie obrad Okragłego Stołu zapomniano o problemach kobiet - „o połowie narodu”26. W wywiadach „Kobiety i Życia” pisano:

... kobiety w świecie polityki sa traktowane jako wieczni terminatorzy, uczennice, produkt niepełny. Bez przerwy muszą udowadniać, że sa niezłe w tym, co robią. To sprawia, że część $z$ nich - najbardziej przedsiębiorcze, ekspansywne i inteligentne rzeczywiście stają się coraz lepsze. Gdyby były mężczyznami, miałyby już bardzo wysokie stanowiska, a tu traca czas na udowadnianie, że są dobre ${ }^{27}$.

Danuta Waniek w wywiadach w „Przyjaciółce” oraz „Kobiecie i Życiu" przekonywała, że wszelkie koszty transformacji systemowej odczuwaja głównie kobiety, co powinno stanowić bodziec do rozwoju organizacji kobiecych. Słusznie zauważono, że inicjatywę kobiet uwolnił projekt ustawy penalizujacej aborcję ${ }^{28}$. Gwałtowny wzrost liczby organizacji kobiecych, mających na celu obronę praw kobiet, rozpoczał się w $1991 \mathrm{r} .{ }^{29} \mathrm{~W}$ sierpniu $1991 \mathrm{r}$. wskazano, że w Polsce jest 20 organizacji kobiecych, $z$ kolei w listopadzie pisano o 30 inicjatywach mających na celu obronę praw kobiet ${ }^{30}$. W tym też roku powstało Parlamentarne Koło Kobiet, w którego prace włączyły się kobiety ze wszystkich ugrupowań parlamentarnych ${ }^{31}$. W wywiadach zachęcano do aktywności politycznej, uświadamiając czytelniczkom, że „uprawiając politykę mamy bezpośredni wpływ na bieg wydarzeń"32.

W „Przyjaciółce” pomoc społeczna była najczęściej pojawiająca się kategoria $\mathrm{w}$ wyselekcjonowanych wywiadach $(32,79 \%$

\footnotetext{
26 Rozmowa Alicji Bińskiej z przewodnicząca Ligi Kobiet Polskich Elżbietą Lęcznarowicz: „Blisko życia zwykłych ludzi”, Ki்̇, nr 23, 7.06.1989, 2.

27 Rozmowa Iwony Konarskiej z Barbara Labuda, przewodniczaca Parlamentarnego Koła Kobiet: „Czarownice w Sejmie”, KiŻ, nr 40, 2.10.1991, 5.

28 Rozmowa Danuty Bierzańskiej z dr Danutą Waniek: „Niebezpieczna nieobecność”; Rozmowa Krystyny Kaszuby z Jolantą Plakiewicz: „Feminizm stowarzyszony”, KiŻ, nr 45, 22.11.1989, 5 .

29 Rozmowa Ruty Pragier z Danutą Waniek, przewodniczaca Demokratycznej Unii Kobiet: „Dziś o tym, czy kobiety potrafią bronić swych praw”, Prz, nr 15, 11.04.1991, 2.

30 Rozmowa Zofii Zubczewskiej z Ewą Łętowską: „Manowce równości”, KiŻ, nr 33, 7.08. 1991, 2; Rozmowa Natalii Iwaszkiewicz z Anną Popowicz, Pełnomocnikiem Rządu ds. Kobiet i Rodziny: „Czy demokracja jest rodzaju męskiego”, KiŻ, nr 45, 6.11.1991, 4.

31 Rozmowa Elżbiety Banasiak z Wiesławą Ziółkowską, przewodniczącą Klubu Polskiej Unii Socjaldemokratycznej, członkinią Parlamentarnego Koła Kobiet: „Dziś o tym, dlaczego potrzebne jest kobiece lobby", Prz, nr 24, 13.06.1991, 2.

32 Rozmowa Grażyny Musiałek z Barbara Labuda, posłanką z Obywatelskiego Klubu Parlamentarnego: „Kwestia temperamentu”, KiŻ, nr 16, 18.04.1990, 2.
} 
wywiadów). Znalazła tu odzwierciedlenie teza o feminizacji biedy w Polsce. „Przyjaciółka” skierowana do mieszkańców wsi i małych miasteczek, częściej dotkniętych bezrobociem i brakiem bezpośredniej pomocy instytucjonalnej informowała o należnych świadczeniach, organizowała samopomoc i pośredniczyła w niej (Fundacja Przyjaciółki, cykl artykułów S.O.S.). W tygodniku „Kobieta i Życie” temat ten podejmowano o wiele rzadziej $(7,14 \%)$, prezentowane w wywiadach wattki związane były $z$ możliwościami przekwalifikowania bezrobotnych. Ta rozbieżność popularności tematyki wywiadów wynikała $z$ różnorodnych adresatów i funkcji pisma. „Przyjaciółka” miała wspierać czytelniczki w trudach życia, podpowiadać, jak wyjść z kryzysu, „Kobieta i Życie” aktywizowała do działania, do samodzielnego znalezienia właściwego rozwiąania.

Tematyka edukacji poruszana $\mathrm{w}$ tygodnikach $\mathrm{w}$ zasadzie ograniczała się do edukacji przedszkolnej. Była to kategoria najrzadziej prezentowana $\mathrm{w}$ kontekście przemian systemowych. W tygodniku „Kobieta i Życie” pojawiła się w 2,38\% wywiadów, w „Przyjaciółce" poświęcono jej $4 \%$ wywiadów. W tym drugim piśmie pozytywnie przyjęto zmiany w prawie i przełamanie monopolu państwa na edukację ${ }^{33}$. Zachęcano czytelniczki do podnoszenia kwalifikacji i dbałości o wykształcenie ${ }^{34}$.

Częściej w wywiadach ukazywano stan polskiej służby zdrowia („Kobieta i Życie” - 4,76\%, „Przyjaciółka” - 5,36\%). Wskazywano na braki środków higienicznych, medykamentów, ale też profilaktyki zdrowotnej i wsparcia dla zdrowia psychicznego.

Tematyka prawna odzwierciedlała listę problemów Polek $\mathrm{w}$ pierwszych latach transformacji systemowej, a więc w dużej mierze zwiazana była $z$ trudna sytuacja finansowa. Częściej tematyka ta obecna była w wywiadach „Przyjaciółki” (7,90\%) niż „Kobiety i Życia" (2,38\%). Informowano więc o możliwościach egzekwowania alimentów, prawie do eksmisji oprawcy $z$ domu rodzinnego. Ale też wyjaśniano codzienne rozterki.

W zdecydowanej większości w obu pismach wywiady dotyczyły problemów i faktów (zur Sache). W „Kobiecie i Życiu” było to

\footnotetext{
33 Rozmowa Elżbiety Szczurowskiej z Edwardem Wieczorkiem, dyrektorem gabinetu ministra edukacji narodowej: „Dziś o ustawie o systemie oświaty”, Prz, nr 36, 5.09.1991, 2.

34 Rozmowa Anny Marii Wiernik z mgr inż. Anną Michalczyk, naczelnikiem Wydziału Spraw Studenckich w Departamencie Nauki i Szkolnictwa Wyższego MEN: „Dziś o tym, czy warto studiować”, Prz, nr 21, 21.05.1992, 2.
} 
$78,57 \%$ wyselekcjonowanych wywiadów, natomiast w „Przyjaciółce” - 93,42\%. Wywiady dotyczace rozmówcy (zur Person) częściej więc pojawiały się w tygodniku „Kobieta i Życie”, było to dostrzegalne w 1989 r. Wówczas na łamach pisma prezentowano sylwetki kandydatów w wyborach parlamentarnych. Wywiady pojawiały się też w 1990 i 1991 r. W „Przyjaciółce” z kolei wywiady o postaciach obecne były wyłącznie w 1989 i 1990 r.

Warto wskazać, że proporcje tematów wywiadów w tygodnikach odzwierciedlały charakter pisma. Tygodnik „Kobieta i Życie” skupiał się głównie na tematyce politycznej i gospodarczej. W dużej mierze tematyka zwiazana była $z$ zaangażowaniem politycznym kobiet, ich miejsca w państwie, konieczności utworzenia kobiecego lobby, praktycznego wymiaru równouprawnienia. Tym samym przesłaniem była aktywizacja czytelniczek do wykorzystania transformacji do zmiany pozycji kobiety w państwie i jej roli społecznej. Informacje o gospodarce przekazywane $\mathrm{w}$ wywiadach pełniły funkcję edukacyjną. W „Przyjaciółce” z kolei struktura tematyczna wywiadów była bardziej zróżnicowana. Najistotniejszą sprawa była pomoc społeczna. W dalszej kolejności podejmowano wątki polityczne i gospodarcze. Skupiano się na negatywnych bieżących skutkach transformacji systemowej. Wywiady zaś ukazywały możliwości przeciwdziałania trudnej sytuacji kobiet. Zatem realizowały one funkcję interwencyjna, mająca na celu poprawę jakości życia polskich kobiet.

\section{Życie kobiet w czasie transformacji systemowej}

Obraz życia kobiet, który wyłaniał się $z$ wywiadów zamieszczonych w prasie dla kobiet, należy zrekonstruować, biorąc pod uwage konkretne pismo. W tygodnikach dostrzec można zbieżność tematów, co świadczy o ich aktualności w badanym okresie. Jednakże zdarzały się też różnice $\mathrm{w}$ prezentacji tematyki. Jak zostało już wskazane, pisma miały dokładnie określonego adresata. Już dominujące kategorie tematów pozwoliły na wyciagnięcie szczątkowych wniosków, które sprawy były najistotniejsze dla czytelników prasy dla kobiet oraz jakie funkcje przez to pełniła.

W obu pismach dostrzegano niereprezentatywność kobiet w polityce. Obecny był obraz życia politycznego zdominowanego przez mężczyzn, którzy nie dostrzegali potrzeby konsultacji projek- 
tów ustaw z kobietami, również tych zwyczajowo rozumianych jako „kobiece”. W zamieszczonych wywiadach na łamach „Przyjaciółki” i „Kobiety i Życia” zwracano uwage na konieczność wejścia kobiet do polityki ogólnopolskiej, aby ich problemy były zauważalne ${ }^{35}$. W jednym $z$ wywiadów „Przyjaciółki” pojawił się wniosek, że należy "Odkobiecić kwestie uważane za kobiece, bo to sa sprawy wszyst-

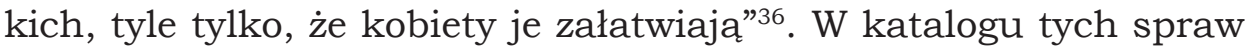
były: troska o aprowizację, ubrania, opiekę nad dziećmi, budżet domowy, edukację, zdrowie rodziny, warunki pracy.

W wywiadach opublikowanych w tygodnikach kreślono obraz Polki, która formalnie była równoprawna mężczyźnie ${ }^{37}$, lecz praktyka życia czyniła ją nierównoprawna ${ }^{38}$. W jednej $z$ wypowiedzi pojawiło się sformułowanie: „Nie chcę, żeby ktoś myślał o mnie jak o kobiecie, lecz jak o człowieku"39. Nierówności dostrzegano w życiu zawodowym, politycznym, rodzinnym. Zauważono, że kobiety w Polsce nie były szanowane jako pracownice. W pierwszej kolejności zwalniano je $z$ pracy, a ich zarobki były niższe, szczególnie kiedy wracały do życia zawodowego po urlopach macierzyńskich. Dostrzegano, że sektory gospodarki zdominowane przez kobiety były niedoinwestowane, czego egzemplifikacja była służba zdrowia. W Polsce nie było też ochrony pracy kobiet w ciąży oraz będacych $\mathrm{w}$ wieku przedemerytalnym ${ }^{40}$. Nierówności uwidaczniały się

35 Zob. Rozmowa Barbary Sass z Ilona Kondrat: „Damskie lobby”, KiŻ, nr 16, 19.04.1989, 9; Rozmowa Wiesławy Piątek z Anną Szymańską-Kwiatkowską: „Popieramy Annę Szymańska -Kwiatkowska”, Prz, nr 22, 4.06.1989, 4.

36 Rozmowa Ruty Pragier z doc. Danuta Markowską: „Dziś o tym, czy w Polsce potrzebna jest partia kobiet”, Prz, nr 13, 29.03.1990, 2.

37 Badania Banku Światowego (Departamentu Walki z Ubóstwem i Zarzązania Gospodarką. Region Europy i Azji Środkowej) z 2004 r. wykazały, że polskie prawo zapewnia równouprawnienie płci. Jednakże narzucona przez tradycję rola kobiet czyni je zależne od rodziny. Sa bowiem odpowiedzialne za dzieci, niepełnosprawnych oraz starszych członków rodziny oraz za położenie materialne rodziny. Mimo wysokich kwalifikacji kobiety zarabiaja mniej niż mężczyźni i rzadziej awansuja. Bank Światowy, Płeć a możliwości ekonomiczne w Polsce: czy kobiety stracity na transformacji?. Raport nr 29205, 2004, IX.

38 Rozmowa Alicji Bińskiej z przewodnicząca Ligi Kobiet Polskich Elżbietą Lęcznarowicz; Rozmowa Natalii Iwaszkiewicz z Barbara Malak, rzecznikiem prasowym Komisji Krajowej NSZZ „Solidarność”, KiŻ, nr 33, 15.08.1990, 2-3; Rozmowa Natalii Iwaszkiewicz z Anną Popowicz.

39 Rozmowa Natalii Iwaszkiewicz z Barbara Malak, rzecznikiem prasowym Komisji Krajowej NSZZ „Solidarność”, KiŻ, nr 33, 15.08.1990, 2-3.

40 Rozmowa Krystyny Kaszuby z wicemarszałkiem Sejmu dr Olgą Krzyżanowską: „Sytuacja tworzy polityka”, Ki்̇, nr 50, 27.12.1989, 2-3; Rozmowa Ruty Pragier z doc. Danuta Markowska; Rozmowa Ruty Pragier z doc. dr hab. Danutą Graniewską: „Dziś o bezrobociu wśród samotnych matek i ojców", Prz, nr 7, 13.02.1992, 2. 
w awansach zawodowych. W 1989 r. wskazano, że tylko 4\% kobiet zajmowało stanowiska dyrektorskie ${ }^{41}$. $Z$ wywiadów wyłaniał się obraz kobiet, które mimo wykształcenia i predyspozycji nie sprawuja stanowisk samodzielnych ${ }^{42}$.

Zauważono, że ignoruje się też kobiety polityków, a ośrodki badania opinii publicznej nie umieszczaja ich nazwisk na listach najpopularniejszych działaczy politycznych ${ }^{43}$. Ponadto w okresie kampanii wyborczej żadna partia nie odnosiła się do kobiecego elektoratu ${ }^{44}$. Niewielka była reprezentacja kobiet w rzadach (dwie w rządzie Tadeusza Mazowieckiego, w rządzie Jana Krzysztofa Bieleckiego żadnej do momentu nominacji Henryki Bochniarz). Kobiety były za to wiceministrami - zatem podobnie jak w gospodarce - zastępcami skupionymi na realizacji zadań ${ }^{45}$. Odmiennie było na niwie działań społecznych, gdzie kobiety gremialnie organizowały się i nie były blokowane przez mężczyzn ${ }^{46}$. Za szczególny przejaw dyskryminacji uznano projekt penalizujaccy aborcję. Na łamach „Kobiety i Życia” projekt ustawy o prawnej ochronie dziecka poczętego traktowano jako wymierzony w prawa i wolności kobiet ${ }^{47}$.

W obu tygodnikach za idealny wzorzec życia rodzinnego uznano partnerski model rodziny ${ }^{48}$. Zauważano, że jeśli partnerstwo będzie obecne w rodzinie, to przełoży się ono również na sferę aktywności politycznej ${ }^{49}$. W „Przyjaciółce” sprzeciwiano się „karykaturalnemu modelowi kobiety umęczonej, z siatkami”, zgadzającej na to, aby to mężczyźni decydowali o jej życiu. Kobieta powinna

\footnotetext{
41 Rozmowa Wiesławy Piątek z Anną Szymańską-Kwiatkowską.

42 Rozmowa Mirosławy Grzeszak z Niną Simakową: „Niełatwo być uczoną”, Prz, nr 23, 8.06.1989, 5 .

43 Rozmowa Iwony Konarskiej z Barbarą Labudą.

44 Andrzej Micewski stwierdził, że w Polsce kampanie wyborcze są prowadzone niefachowo, brakuje rozwiązań programowych, do kobiet zaś należy zwracać się programem, Rozmowa Janusza Miliszkiewicza z Andrzejem Micewskim: „Zawód: Polityk”, Ki̇̇, nr 6, 5.02.1992, 2.

45 Rozmowa Natalii Iwaszkiewicz z Anną Popowicz.

46 Rozmowa Zygmunta Włoczewskiego z Małgorzatą Kielską-Żukowską: „Chcemy się rządzić sami", Prz, nr 16, 19.04.1990, 5.

47 Rozmowa Elżbiety Wierzbickiej z Iris Rossini: „Zdziwione cudzoziemki”, Ki்̇, nr 34, 22.08.1990, 2-3; Rozmowa Elżbiety Wierzbickiej z senator Anną Bogucką-Skowrońską: „Przed decyzja”, KiŻ, nr 37, 12.09.1990, 5; Rozmowa Marii Mankiewicz z Anną Popowicz: „Dywan z małych kawałków”, Ki்̇, nr 18, 1.05.1991, 5; Rozmowa Zofii Zubczewskiej z Ewa Łętowską: „Manowce równości”, KiŻ, nr 33, 7.08.1991, 2.

48 Rozmowa Elżbiety Szczurowskiej z Januszem Baranowskim, prezesem Spółdzielczego Zakładu Ubezpieczeń WESTA: „Dziś o kobietach”, Prz, nr 10, 8.03.1990, 2.

49 Rozmowa Krystyny Kaszuby z wicemarszałkiem Sejmu dr Olga Krzyżanowską.
} 
mieć wybór, czy chce pracować, czy zająć się dziećmi ${ }^{50}$. Uważano, że kobieta pracująca w domu powinna otrzymywać zasiłek dla bezrobotnych, następnie mieć prawo do najniższej emerytury ${ }^{51}$. Jako przykład prawnej dyskryminacji kobiet przywołano zwolnienia na opiekę nad dziećmi przysługujące wyłącznie matkom. $Z$ tego tytułu były one traktowane jako pracownicy mniej wartościowi. Kolejna kwestia były sprawy mieszkaniowe i sytuacja kobiet, które dzieliły wbrew wyrokowi sądu mieszkanie $z$ agresorem ${ }^{52}$. Pojawiły się sformułowania „dałyśmy się zwariować na tę dzielność”, sugerujące, że presja ekonomiczna i psychologiczna skutkowała rezygnacją kobiet $z$ własnego modelu życia ${ }^{53}$.

Obraz życia kobiet w perspektywie gospodarczej można było zrekonstruować na podstawie wywiadów w „Przyjaciółce”, w których ukazywano nieustanna walkę o produkty żywnościowe, permanentne problemy $z$ budżetem domowym (obniżenie wynagrodzeń), strach przed utrata pracy ${ }^{54}$. O ile w 1989 r. dostrzegano nadzieję na poprawę jakości życia, o tyle pod koniec 1990 r. pisano: „W zeszłym roku Okragły stół wydawał się cudem, dziś już nie śpiewamy "Ojczyznę wolną racz nam zwrócić Panie»"55. W $1991 \mathrm{r}$. w wywiadach pojawily się opinie, że reformy gospodarcze postępuja zbyt szybko ${ }^{56}$. Podkreślano, że skutki bezrobocia moga dotknąc 40\% społeczeństwa (4,5 mln dorosłych Polaków), a utrata zarobków kobiety to czterokrotne zubożenie rodziny, którego nie wyrównają zasiłki (stanowiące 30\% zarobków) ${ }^{57}$. Pesymistyczną wizję życia rodziny równoważyła obecna w wywiadach kafeteria możliwości przeciwdziałania nędzy. $Z$ jednej bowiem strony informowano, że przedsiębiorstwa będą kontynuowały zmniejszanie stanu zatrudnienia, $z$ drugiej zaś strony przedstawiano to jako szansę na za-

\footnotetext{
50 Rozmowa Anny Sułkowskiej z Anną Szymańską-Kwiatkowską: „2000 razy kobieta”, Prz, nr 41, 12.10.1989, 6-7.

51 Rozmowa Iwony Konarskiej z Barbara Labudą.

52 Rozmowa Marii Mankiewicz z Anną Popowicz.

53 Rozmowa Ruty Pragier z doc. Danutą Markowską.

54 Rozmowa Ewy Łuszczuk z ministrem Mieczysławem Wilczkiem: „To panie wybieraja!”, Prz, nr 10, 9.03.1989, 3.

55 Rozmowa Ruty Pragier z pracownikami Zakładów Mechanicznych im. Nowotki w Warszawie: Marią Niemczuk, Elżbietą Ramonotowską, Bogusławem Strzemiecznym, Wojciechem Sielużyckim: „Ile cierpliwości, ile nadziei?”, Prz, nr 31, 2.08.1990, 4.

56 Rozmowa Elżbiety Banasiak z dr. Ryszardem Bugajem, posłem na Sejm, przewodniczącym Sejmowej Komisji Polityki Gospodarczej, Budżetu i Finansów, Prz, nr 27, 4.07.1991, 2, 4.

57 Rozmowa Elżbiety Banasiak z Wandą Sokołowską, posłanką: „Remanent damskich spraw", Prz, nr 4, 24.01.1991, 4-5.
} 
łożenie własnej działalności gospodarczej, prezentując wskazówki i porady prawne, w jaki sposób można otworzyć warsztat, sklep, kantor czy firmę usługową ${ }^{58}$. Zachęcano do zakupu akcji przedsiębiorstw państwowych ${ }^{59}$. Informowano o nowych działaniach rządu, mających przeciwdziałać kryzysowi, jak np. powstanie Agencji Rozwoju Regionalnego w Łodzi, która miała wspomóc restrukturyzację przedsiębiorstw $^{60}$. Uspokajano też czytelniczki, że nowy system podatkowy nie doprowadzi gospodarstw domowych do ruiny ${ }^{61}$.

Biorąc pod uwagę kategorię „pomoc społeczna”, można zauważyć, że wzrost bezrobocia kobiet oraz spadek wynagrodzeń skutkował zainteresowaniem czytelników możliwościami uzyskania pomocy. Poruszana tematyka zogniskowana była wokół spraw bliskich kobietom, np. alimentów ${ }^{62}$. Wywnioskować więc można, że w okresie przemian transformacyjnych kobiety miały problem $z$ egzekwowaniem alimentów od ojców dzieci, co odzwierciedlają też wywiady, w których podejmowano wątek zmieniającego się prawa. Wraz z pogłębiającym się ubóstwem i wzrostem cen (energii elektrycznej, gazu, wody, czynszów) na łamach „Przyjaciółki” pojawiały się wywiady $z$ ekspertami o formach pomocy społecznej oraz warunkach uzyskania świadczeń ${ }^{63}$. Tłumaczono, jak uzyskać kredyt

\footnotetext{
58 Rozmowa Wiesławy Piątek ze Stanisławem Chełstowskim, redaktorem naczelnym „Życia Gospodarczego”: „Dziś o tym, jak się odnaleźć w trudnej rzeczywistości”, Prz, nr 24, 14.06.1990, 2.

59 Rozmowa Andrzeja Zarzeckiego z Jackiem Bukowskim, doradcą ministra finansów, wicedyrektorem Biura Pełnomocnika Rządu ds. Przekształceń Własnościowych: „Dziś o prywatyzacji polskiej gospodarki”, Prz, nr 34, 23.08.1990, 2.

60 Rozmowa Wiesławy Piątek z Henryka Bochniarz, ministrem przemysłu i handlu: „Trzeba pomóc dobrym", Prz, nr 42, 17.10.1991, 3.

61 Rozmowa Andrzeja Zarzeckiego z Danutą Demaniuk, podsekretarzem stanu w Ministerstwie Finansów: „Dziś o tym, czy nowy system podatkowy zagrozi naszym portfelom”, Prz, nr 34, 22.08.1991, 2; Rozmowa Zygmunta Włoczewskiego z Hubertem Mikołajczykiem, głównym specjalistą w departamencie podatków i opłat Ministerstwa Finansów: „Dziś o tym, czy trzeba bać się powszechnego podatku dochodowego", Prz, nr 1, 2.01.1992, 2.

62 Rozmowa Ruty Pragier z Anną Kędzierska, Pełnomocnikiem Rządu ds. Kobiet: „Zmiany wymaga nie tylko fundusz alimentacyjny”, Prz, nr 24, 15.06.1989, 5; Rozmowa Zdzisławy Jucewicz z sędzią Markiem Dobrowolskim: „Dziś o alimentach”, Prz, nr 13, 16.03.1992, 2.

63 Rozmowa Andrzeja Zarzeckiego z Andrzejem Kuzińskim, starszym specjalista w Departamencie Pomocy Społecznej Ministerstwa Pracy i Polityki Socjalnej: „Dziś o tym, kto otrzyma pomoc w opłatach za mieszkanie”, Prz, nr 32, 9.07.1990, 2; Rozmowa Wiesławy Piątek z Barbara Galas, kierownikiem działu pomocy środowiskowej w śródmiejskim Centrum Pomocy Społecznej w Warszawie: „Dziś o dopłatach do mieszkań”, Prz, nr 4, 24.01.1991, 2; Rozmowa Wiesławy Piątek z Aurelią Trzcińską, głównym specjalistą w Departamencie Pomocy Społecznej Ministerstwa Pracy i Polityki Socjalnej: „Dziś o dopłatach do świadczeń za mieszkania”, Prz, nr 32, 8.08.1991, 2; Rozmowa Ruty Pragier z Aurelią Trzcińska, głównym specjalista w Departamencie Pomocy Społecznej w Ministerstwie Pracy i Polityki Socjalnej: „Dziś o osłonie
} 
na mieszkanie spółdzielcze ${ }^{64}$. Wiele wywiadów było źródłem informacji o zasiłkach dla bezrobotnych oraz możliwościach przekwalifikowania ${ }^{65}$.

W obu pismach za istotna sprawę uznano kwestię przedszkoli. W „Przyjaciółce” niepokój redakcji wywołał wzrost opłat za przedszkola. Zauważono, że będzie to skutkowało rezygnacją z posyłania do nich dzieci, a tym samym wycofaniem się kobiet $z$ przestrzeni zawodowej6 ${ }^{66}$ W „Kobiecie i Życiu” ukazywano słaby stan polskich przedszkoli, w tym niedostosowany do przemian społecznych schemat organizacyjny z przełomu lat 40. i 50 . XX w., tendencje do realizacji funkcji wychowawczych i opiekuńczych narzucanych przez państwo socjalistyczne ${ }^{67}$.

W wywiadach zamieszczonych na łamach prasy dla kobiet odnoszono się do tematyki zdrowotnej. Częściej problematykę tę podejmowano w „Przyjaciółce”. Zwracano uwagę, że w Polsce brakuje podstawowych środków higienicznych dla kobiet (tj. waty, ligniny, podpasek), ale rozmówcy uspokajali czytelniczki, że tworzone linie produkcyjne zapewnią większe dostawy. Na półkach aptek brakowało środków antykoncepcyjnych ${ }^{68}$. Watek ten pojawił się również w tygodniku „Kobieta i Życie”. W zamieszczonym tam

socjalnej z powodu wzrostu opłat za ogrzewanie, ciepłą wodę, elektryczność i gaz", Prz, nr 6, 6.02.1992, 2; Rozmowa Elżbiety Banasiak-Chmury z dr. Wojciechem Sadowskim, dyrektorem Ośrodka Pomocy Społecznej na warszawskim Mokotowie: „Dziś o tym, w czym może Ci pomóc opieka społeczna”, Prz, nr 28, 9.07.1992, 2.

64 Rozmowa Wiesławy Piątek $z$ dr. Jerzym Zdrzałka, podsekretarzem stanu w Ministerstwie Gospodarki Przestrzennej i Budownictwa: „Dziś o kredytach mieszkaniowych”, Prz, nr 11, 14.03.1991, 2; Rozmowa Zygmunta Włoczewskiego ze Zdzisławem Gryszka, naczelnikiem wydziału w departamencie polityki mieszkaniowej i gospodarki miejskiej w Ministerstwie Gospodarki Przestrzennej i Budownictwa: „Dziś o nowych zasadach finansowania budownictwa mieszkaniowego”, Prz, nr 4, 23.01.1992, 2; Rozmowa Zdzisławy Jucewicz z Aurelia Trzcińską, głównym specjalista w Departamencie Pomocy Społecznej Ministerstwa Pracy i Polityki Socjalnej: „Dziś o dopłatach do mieszkań”, Prz, nr 43, 22.10.1992, 5.

65 Rozmowa Wiesławy Piątek z Piotrem Mrukiem, dyrektorem Departamentu Zatrudnienia w Ministerstwie Pracy i Polityki Socjalnej: „Dziś o nowym prawie dla bezrobotnych”, Prz, nr 39, 26.09.1991, 2, 4; Rozmowa Zdzisławy Jucewicz z Tadeuszem Olejarzem, wicedyrektorem Departamentu Zatrudnienia w Ministerstwie Pracy i Polityki Socjalnej: „Dziś o tym, czego moga oczekiwać bezrobotni”, Prz, nr 49, 3.12.1992, 5; Rozmowa Zygmunta Włoczewskiego z Bartłomiejem Piotrowskim, podsekretarzem stanu w Ministerstwie Pracy i Polityki Socjalnej: „Dziś o możliwościach przekwalifikowania bezrobotnych”, Prz, nr 47, 21.11.1991, 2.

66 Rozmowa Anny Marii Wiernik z mgr Marią Mrówczyńską, dyrektorką Państwowego Przedszkola Ćwiczeń: „Dziś o tym, co robić, by przedszkola były tańsze”, Prz, nr 22, 31.05.1990, 2. 67 Rozmowa Olgi Oswald z Marią Mrówczyńską: „Sposoby na przedszkole”, KiŻ, nr 18, 3.05.1989, 2.

68 Rozmowa Teresy Kaliny z prof. dr hab. Izabelą Płaneta-Małecka, minister zdrowia i opieki społecznej: „Chcemy, aby pacjenci byli zadowoleni”, Prz, nr 17, 27.04.1989, 5. 
wywiadzie zwracano uwage, że Polki (w tym studentki medycyny) nie posiadają wiedzy o antykoncepcji, co może przyczyniać się do wzrostu liczby aborcji ${ }^{69}$. Wyłącznie w wywiadach w „Przyjaciółce” wskazywano na skutki zdrowotne (psychiczne i fizyczne) aborcji ${ }^{70}$. W tygodniku tym dostrzegano także trudne warunki szpitali oraz brak profilaktyki w zakresie nowotworów, powołując się na statystyki, w których śmiertelność Polek z powodu nowotworów była najwyższa w Europie ${ }^{71}$.

$\mathrm{Za}$ istotna kwestię w obu tygodnikach uznano brak wsparcia terapeutycznego dla kobiet, które doświadczyły kryzysu psychicznego, przemocy i uzależnienia ${ }^{72}$. W „Przyjaciółce” zauważono, że przeciążone fizycznie (nadmiar obowiazków domowych, praca na nocne zmiany, kilka etatów) i psychicznie (strach przed bezrobociem i nędza) kobiety rodza przedwcześnie lub rodza dzieci $z$ wadami rozwojowymi ${ }^{73}$. $Z$ wywiadów umieszczonych na łamach prasy dla kobiet $\mathrm{w}$ badanym okresie dostrzec można, że kobiety nie miały wsparcia instytucjonalnego. Brak badań profilaktycznych, brak środków higienicznych, brak wsparcia terapeutycznego czynił je zależne od własnej zaradności i wsparcia rodziny.

Ostatnią kategoria tematyczna wywiadów, ukazująca przemiany systemowe, było prawo. Na łamach „Przyjaciółki” wyjaśniano zmiany prawne i zachęcano do ich śledzenia ${ }^{74}$. Wywiady ze specjalistami $z$ danej dziedziny były odpowiedzia na obawy czytelników wyrażone w listach do redakcji. Podejmowano w nich kwestie zmian politycznych, w tym ordynacji wyborczej ${ }^{75}$. Rozwiewano obawy czytelniczek związane $z$ utrata ogrodów działkowych. Wynikały one $z$ likwidacji organów pracowniczych ogródków dział-

\footnotetext{
69 Rozmowa Wandy Bogusławskiej z Małgorzata Bińkowską: „Pigułka czy spirala?”, KiŻ, nr 1, 4.01.1989, 17.

70 Rozmowa Aliny Czerskiej z dr. Januszem Wojewódzkim, ginekologiem położnikiem: „To musisz wiedzieć", Prz, nr 22, 31.05.1990, 6.

71 Rozmowa Ruty Pragier z Zofią Kuratowska, wicemarszałkiem Senatu: „Dziś o służbie zdrowia i prawach kobiet", Prz, nr 42, 7.11.1991, 1, 5.

72 Rozmowa Ruty Pragier $z$ Susan Vandiver, dyrektorem wykonawczym organizacji Służba na Rzecz Rodziny w Bostonie: „Zacząć od spraw najprostszych”, Prz, nr 18, 3.05.1990, 6; Rozmowa Teresy Gałczyńskiej z Ewą Osiatyńską: „Wernisaż dusz”, Ki்̇, nr 2, 11.01.1989, 17.

73 Rozmowa $z$ dr Aliną Włodarzowa, lekarką: „Profilaktyka przede wszystkim”, Prz, nr 4, 24.01.1991, 5.

74 Rozmowa Elżbiety Banasiak z Andrzejem Dobrzyńskim: „Dziś o tym, dlaczego warto śledzić zmieniające się prawo", Prz, nr 28, 12.07.1990, 2.

75 Rozmowa Elżbiety Banasiak z Jerzym Stępniem, senatorem, generalnym komisarzem wyborów: „Dziś o wyborach do samorządu terytorialnego”, Prz, nr 18, 3.05.1990, 2.
} 
kowych ${ }^{76}$. Wyjaśniano też prawo dotyczące eksmisji ${ }^{77}$ oraz zaznajamiano czytelników $z$ prawami konsumenta ${ }^{78}$. W obu tygodnikach interesowano się zmianami $\mathrm{w}$ prawie pracy i ochroną pracy kobiet $^{79}$.

Obraz życia kobiet w wywiadach zamieszczonych w prasie dla kobiet ukazywał ich niedecyzyjność w zakresie polityki i gospodarki. Mimo braku oddziaływania na kształt reform w Polsce kobiety ponosiły ich największe koszty. Wzrost cen przedszkoli przy spadku wysokości wynagrodzeń pozbawiał je prawa do pracy. Przepis, że zasiłek opiekuńczy na dziecko należy wyłącznie do kobiet, czynił je mniej wartościowym pracownikiem. $Z$ tego względu bezrobocie w okresie transformacji ustrojowej dotknęło w pierwszej kolejności kobiety. Pozbawione źródeł dochodu w prasie poszukiwały pomocy i recepty na swoje problemy.

Kobiety w pierwszych latach transformacji systemowej były dyskryminowane i pozbawiane prawa do decydowania o macierzyństwie i ścieżce życia. Było to też skutkiem dominacji tradycyjnego modelu rodziny. Płeć stanowiła również barierę awansu. Warto wskazać, że o ile w „Przyjaciółce” diagnoza sytuacji kobiet skłaniała redakcję do pomocy, to zespół „Kobiety i Życia” do aktywizowania czytelniczek do działania.

\footnotetext{
76 Rozmowa Elżbiety Banasiak z Marią Sielicką-Gracką, posłanką OKP, współautorką projektu ustawy o ogródkach działkowych: „Dziś o obawach działkowiczów”, Prz, nr 39, 27.09.1990, 2 .

77 Rozmowa Ruty Pragier z Jerzym Krzekotowskim, naczelnikiem Wydziału Gospodarki Lokalowej w Ministerstwie Gospodarki Przestrzennej i Budownictwa: „Dziś o sprawach eksmisji w nowym prawie mieszkaniowym”, Prz, nr 2, 9.01.1992, 2; Rozmowa Zygmunta Włoczewskiego $z$ Włodzimierzem Jurkowskim, przewodniczącym oddziału warszawskiego Zrzeszenia Lokatorów: „Dziś o tym, jak pomagać lokatorom”, Prz, nr 46, 5.11.1990, 2.

78 Rozmowa Wiesławy Piątek z Małgorzata Niepokulczycką: „Dziś o prawach klienta”, Prz, nr 9, 28.02.1991, 2.

79 Rozmowa Ruty Pragier z Elżbietą Szemplińską, głównym specjalistą Ministerstwa Pracy i Polityki Socjalnej: „Dziś o tym, na co należy zwracać uwagę w prywatnym zakładzie”, Prz, nr 49, 6.12.1990, 2; Rozmowa Ruty Pragier z Elżbietą Szemplińska, głównym specjalista Ministerstwa Pracy i Polityki Socjalnej: „Co się zmieniło, a co nie w prawach pracownika”, Prz, nr 45, 8.11.1990, 5; Rozmowa Zdzisławy Jucewicz z Marią Kaczor, główna specjalistką w Departamencie Prawnym Głównego Inspektoratu Pracy Państwowej Inspekcji Pracy: „Dziś o ochronie pracy kobiet”, Prz, nr 5, 30.01.1992, 2; Rozmowa Renaty Marzewskiej z Renata Grabską: „Kobieta wytrzyma więcej”, Kï̇, nr 5, 1.02.1989, 2-3.
} 


\section{Interlokutorzy}

Jak zaznaczył Michał Szulczewski,

wywiad stanowi publikacje rozmowy przeprowadzonej przez dziennikarza $z$ człowiekiem reprezentujaccym coś w danej dziedzinie. Reprezentowanie to można rozumieć jako zajmowanie wybitnej pozycji w zakresie jakichś spraw publicznych np. politycznych, gospodarczych, a także posiadanie autorytetu ze względu na swoje osiagnięcia artystyczne, naukowe, sportowe lub pracę zawodowa ${ }^{80}$.

Badania wykazały, że w „Kobiecie i Życiu” 78,57\% interlokutorów było kobietami, w „Przyjaciółce” liczba kobiet nieznacznie przewyższała liczbę mężczyzn - 59,35\%. Można wysnuć wniosek, że nastawiona na walkę o równouprawnienie kobiet redakcja „Kobiety i Życia" celowo zadbała o te proporcje, udowadniajac, że kobiety te $\dot{z}$ sa autorytetami i ekspertami.

$\mathrm{W}$ obu pismach w doborze interlokutora zwracano uwage na jego kompetencje zawodowe i kwalifikacje. W badanej prasie dla kobiet można wyszczególnić kilka kategorii rozmówców: autorytet naukowy (profesor, autor publikacji naukowej, wypowiadajacy się w badanej problematyce, stawiajacy diagnozy), autorytet zawodowy (osoba zajmująca się konkretnym wycinkiem rzeczywistości, np. lekarz, psycholog, urzędnik - często na stanowisku kierowniczym, nauczyciel, sędzia), polityk (reprezentant narodu - poseł, senator, radny), autorytet polityczny (minister i wiceminister), zwykły człowiek (pracownik, aktywista społeczny) (zob. wykres nr 2).

Redakcja „Kobiety i Życia” do rozmowy zapraszała zdecydowanie częściej polityków (42,86\%), autorytety zawodowe $(26,19 \%)$ oraz autorytety polityczne $(21,43 \%)$. Rzadko przeprowadzano wywiady $z$ autorytetami naukowymi $(7,14 \%)$ i zwykłymi ludźmi $(2,38 \%)$. Stosując zmienna płci, można zauważyć, że w zdecydowanej większości kategorii dominowały rozmówczynie (zwykły człowiek - 100\%, autorytet zawodowy - 90\%, autorytet polityczny - 66,67\%, polityk - 65\% kobiet). Taka sama liczba rozmówców - kobiet i mężczyzn

\footnotetext{
80 Michał Szulczewski, „Informacja”, w: Bartłomiej Golka, Mieczysław Kafel, Zbigniew Mitzner (red.), Teoria i praktyka dziennikarstwa. Wybrane zagadnienia, (Warszawa: Państwowe Wydawnictwo Naukowe, 1964), 9; zob. też: Małgorzata Kita, „Wywiad jako gra. "Aktorzy" wywiadu z perspektywy paratekstualnej”, w: Ewa Jędrzejko, Urszula Żydek-Bednarczuk (red.), Gry w języku i kulturze, (Warszawa: Energia, 1997), 91-92; Barbara Sobczak, Wywiad telewizyjny na żywo, 24.
} 


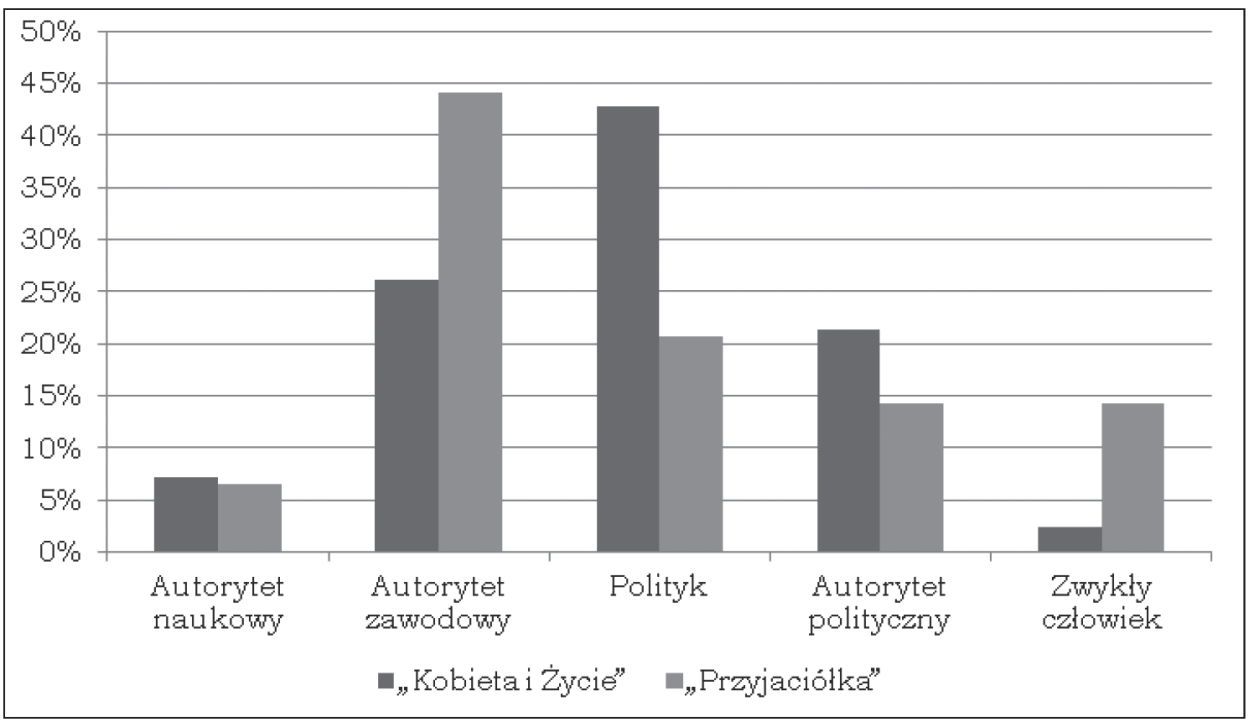

Wykres nr 2. Kategorie rozmówców wywiadów w badanej prasie dla kobiet (1989-1992)

Źródło: Opracowanie na podstawie badań własnych.

były wyłącznie w kategorii „autorytet naukowy”. Rzadko w badanym okresie pojawiał się więcej niż jeden wywiad $z$ tym samym rozmówca. W zasadzie dwukrotnie (w rocznych odstępach) przeprowadzono rozmowy z posłem Ryszardem Bugajem oraz z pełnomocnik rządu ds. kobiet i rodziny - Anną Popowicz.

Redakcja „Przyjaciółki” z kolei najczęściej przeprowadzała wywiady $z$ autorytetami zawodowymi, głównie specjalistami $z$ urzędów i ministerstw $(44,16 \%)$, następnie $z$ politykami $(20,78 \%)$. Taka sama liczba wywiadów pojawiła się $z$ autorytetami politycznymi i zwykłymi ludźmi (14,28\%). Rzadko (podobnie jak w tygodniku „Kobieta i Życie") do rozmowy zapraszano autorytety naukowe $(6,5 \%)$. Stosując zmienna płci, można dostrzec, że w wywiadach na łamach „Przyjaciółki” rozmówczynie dominowały w kategoriach: autorytet naukowy $(80 \%)$, zwykły człowiek $(55,56 \%)$, polityk $(53,33 \%)$. Taka sama liczba rozmówców - kobiet i mężczyzn obecna była w kategorii autorytet polityczny. Mężczyźni z kolei dominowali wśród rozmówców z kategorii autorytet zawodowy (54,05\%).

Na łamach „Przyjaciółki” w badanym okresie, podobnie jak w „Kobiecie i Życiu”, rzadko przeprowadzano dwukrotnie wywiad 
$z$ tą samą osobą. Przykładem była redaktor naczelna „Kobiety i Życia” Anna Szymańska-Kwiatkowska (wywiady przed wyborami parlamentarnymi, w których kandydowała), Elżbieta Szemplińska (specjalistka w Ministerstwie Pracy i Polityki Socjalnej), Zofia Kuratowska (wicemarszałek Senatu), Jerzy Krzekotowski (naczelnik Wydziału Gospodarki Lokalowej w Ministerstwie Gospodarki Przestrzennej i Budownictwa). Trzy wywiady w badanym okresie przeprowadzono z kolei z Aurelią Trzcińską (główna specjalistką w Departamencie Pomocy Społecznej w Ministerstwie Pracy i Polityki Socjalnej).

Można zatem sformułować wniosek, że w obu pismach kobiety jako rozmówczynie dominowały w kategoriach „zwykły człowiek” oraz „polityk”. Natomiast charakter pisma i jego główna funkcja wpłynęły też na wybór rozmówców. Aktywizacyjny charakter „Kobiety i Życia” przyczynił się do popularyzacji kobiet w wywiadach, które podkreślały ich kompetencje, kwalifikacje, stanowisko. Z kolei w „Przyjaciółce”, w której dominowała funkcja interwencyjna i pomocowa, kobiety ukazywano jako autorytety naukowe, polityków oraz zwykłych ludzi.

\section{Podsumowanie}

Analiza wywiadów dotyczących transformacji systemowej pozwoliła na rekonstrukcję obrazu życia kobiet w Polsce w pierwszych latach przemian. Zdecydowana większość wywiadów zarówno w tygodniku „Kobieta i Życie”, jak i w tygodniku „Przyjaciółka” dotyczyła faktów (zur Sache). Poruszaną tematykę można zaklasyfikować do sześciu kategorii: gospodarki, polityki, pomocy społecznej, edukacji, służby zdrowia, prawa. Były to najbardziej newralgiczne obszary, wpływające na życie codzienne, które w badanym okresie podlegały przeobrażeniom.

Należy zaznaczyć, że w każdym $z$ tygodników w wywiadach dominowały odmienne kategorie. Było to zwiazane $z$ innym adresatem pisma i założeniami redakcji co do głównej funkcji pełnionej przez tygodniki. W tygodniku „Kobieta i Życie” najczęściej poruszano tematykę dotyczaca polityki i gospodarki. Uwaga rozmówców ogniskowała się wokół równouprawnienia płci w polityce, życiu zawodowym i rodzinnym. Wyraźna była też funkcja aktywizujacca, 
mająca zachęcić czytelniczki do działania na niwie politycznej, ale też gospodarczej. W tygodniku „Przyjaciółka” najczęściej w wywiadach pojawiały się tematy zwiazane $z$ pomoca społeczną. Redakcja włączała się w akcje pomocowe dla dotkniętych ubóstwem i bezrobociem rodzin czytelników. Radziła czytelnikom, jak wyjść z trudnej sytuacji życiowej. W dalszej kolejności uwaga redakcji skierowana była na tematy polityczne i gospodarcze.

W zależności od tygodnika odmiennie ukazywano transformację systemową. W tygodniku „Kobieta i Życie” traktowano ja jako proces konieczny do poprawy jakości życia Polaków. W wywiadach prezentowano diagnozy kolejnych reform, wskazując, że ich konsekwencją będa redukcje zatrudnienia, ale tego wymaga interes demokratycznego państwa. W transformacji dopatrywano się szansy na zmianę pozycji kobiet w Polsce, zwiększenia ich udziału we władzy oraz instytucjonalnym wsparciu w zakresie pokonania barier awansu zawodowego. Za pomoca wywiadów promowano ideę oddolnej integracji kobiet i zakładania nieformalnych organizacji kobiecych. W „Przyjaciółce” wskazywano na zbyt szybki przebieg reform oraz ich negatywne konsekwencje. Starano się jednak równoważyć negatywne diagnozy poprzez promocję form pomocy społecznej.

W wywiadach opublikowanych na lamach „Kobiety i Życia” kobieta była „wojownikiem” o własne prawa, dostrzegała konieczność stworzenia lobby kobiecego. Głośno protestowała wobec dyskryminacji ze względu na płeć, przeciwko przewadze mężczyzn w polityce i na stanowiskach kierowniczych. Domagała się udziału kobiet $\mathrm{w}$ podejmowaniu decyzji kluczowych dla rozwoju państwa, szczególnie w zakresie gospodarki. Ale też była gotowa do „pracy u podstaw" na rzecz rozbudzenia świadomości obywatelskiej u kobiet. W tygodniku przejawiało się to w promowaniu aktywności społecznej, kulturalnej, gospodarczej i politycznej kobiet. W tygodniku „Kobieta i Życie” zdecydowanie jako rozmówcy dominowały kobiety (78,57\% rozmówców). Były ukazywane przede wszystkim jako autorytety zawodowe i polityczne.

W tygodniku „Przyjaciółka” kobieta dopiero przyzwyczajała się do zmian politycznych, odkładajac walkę o urzeczywistnienie zasady równouprawnienia na czas „spokojniejszy”, po wdrożeniu reform koniecznych od poprawy sytuacji gospodarczej kraju. Była świadoma nierówności płci, dostrzegała jej konsekwencje, chociaż- 
by w wysokości płac, zwolnieniach, niereprezentatywności politycznej kobiet. Jednakże była przeciwna strajkom, obawiając się ich konsekwencji - choćby zwolnień grupowych. Poświęcała się więc dla dobra państwa i społeczeństwa. Była obserwatorką transformacji, oczekująca na właściwy moment do zamanifestowania gotowości do udziału w życiu publicznym. Pod koniec 1990 r. redakcja „Przyjaciółki” zdecydowała się na rozmowę ze „statystyczną Pania Kowalska". $Z$ książki telefonicznej wybrano numer do kobiety o tym nazwisku i zapytano ja, czego oczekuje od nowo wybranego prezydenta oraz o czym marzy. Helena Kowalska wskazała, że oczekuje od nowego prezydenta, aby był „opatrznościa dla Polski”, aby dzięki niemu świat zmienił opinię o Polakach. Chciałaby też, aby ludzie byli względem siebie uprzejmi. Jej zaś marzeniem było, aby nie zlikwidowano bibliotek, aby było ją kiedyś stać na zakup ulubionego pisma i wizytę $\mathrm{w}$ kinie oraz teatrze ${ }^{81}$. Warto wskazać, że w „Przyjaciółce” również dominowały kobiety jako rozmówczynie, jednakże ta przewaga nad mężczyznami nie była zbyt duża (59,35\% kobiet). Najczęściej kobiety były ukazywane jako autorytety naukowe.

Reasumując, obraz życia kobiet w wywiadach prasowych był pesymistyczny. Wynikało to $z$,szokowego pogorszenia się jakości życia" w Polsce w latach 1989-199282. Dominującym motywem było rosnace bezrobocie wśród kobiet (ale też mężczyzn) oraz zmiany polityczne, na które nie miały wpływu. $Z$ wywiadów można wywnioskować, że kobiety w Polsce w latach 1989-1992 były obywatelkami drugiej kategorii. Nie decydowały o losach państwa, były ignorowane w przestrzeni publicznej, spadał ich udział w polityce, były ograniczane ich prawa do decydowania o macierzyństwie (projekt ustawy penalizującej aborcję), życiu zawodowym (wzrost cen za żłobki i przedszkola, likwidacja świetlic). Nie miały wsparcia instytucjonalnego $\mathrm{w}$ zakresie profilaktyki zdrowotnej oraz pomocy terapeutycznej. Mimo zagwarantowanego prawnie równouprawnienia nie były równo traktowane w życiu zawodowym oraz w działalności publicznej. Kobiety jako pierwsze były zwalniane $z$ pracy - młodsze ze względu na obowiazki rodzicielskie, starsze $z$ uwagi na mniej-

81 Rozmowa Elżbiety Banasiak z Heleną Kowalską: „Dziś o tym, czego oczekuje pani Kowalska”, Prz, nr 52, 27.12.1990, 2.

82 Piotr Szumlewicz, „Ubóstwo kobiet w Polsce po 1989 roku”, Problemy Polityki Społecznej, nr 15, 2011, 65. 
szą wydajność. Stąd za istotne uznano wdrożenie polityki społecznej państwa w zakresie zagwarantowania alimentów i wsparcia finansowego dla samotnych matek. Kobieta w czasie transformacji ustrojowej była również dyskryminowana w zakresie awansów zawodowych oraz płac. Była ofiara oszczędności w edukacji oraz opiece zdrowotnej.

\section{Bibliografia}

\section{Źródła}

Ustawa konstytucyjna $z$ dnia 17 października 1992 r. o wzajemnych stosunkach między władzą ustawodawczą i wykonawczą Rzeczypospolitej Polskiej oraz o samorządzie terytorialnym, Dz.U. $1992 \mathrm{Nr}$ 84, poz. 426.

Bank Światowy, Płeć a możliwości ekonomiczne w Polsce: czy kobiety straciły na transformacji?. Raport nr 29205, 2004.

\section{Wywiady w tygodniku „Kobieta i Życie” (1989-1992)}

Rozmowa Alicji Bińskiej z przewodnicząca Ligi Kobiet Polskich Elżbieta Lęcznarowicz: „Blisko życia zwykłych ludzi”, KiŻ, nr 23, 7.06.1989.

Rozmowa Barbary Sass z Iloną Kondrat: „Damskie lobby”, KiŻ, nr 16, 19.04.1989.

Rozmowa Danuty Bierzańskiej z prof. Anną Przecławską: „Koło Ratunkowe", Ki்̇, nr 9, 1.03.1989, 4-5.

Rozmowa Danuty Bierzańskiej z dr Danutą Waniek: „Niebezpieczna nieobecność", KIŻ, nr 45, 22.11.1989.

Rozmowa Elżbiety Wierzbickiej z Iris Rossini: „Zdziwione cudzoziemki”, KiŻ, nr 34, 22.08.1990.

Rozmowa Elżbiety Wierzbickiej z senator Anną Bogucką-Skowrońską: „Przed decyzja”, KiŻ, nr 37, 12.09.1990.

Rozmowa Grażyny Musiałek z Barbarą Labuda, posłanką z Obywatelskiego Klubu Parlamentarnego: „Kwestia temperamentu”, KiŻ, nr 16, 18.04.1990.

Rozmowa Grażyny Musiałek z Wiesławą Ziółkowska, posłanką na Sejm: „Reguła wahadła”, KiŻ, nr 47, 6.12.1989.

Rozmowa Grażyny Wróblewskiej z dr. Ryszardem Bugajem, ekonomista, posłem na Sejm: „Punkt ryzyka”, KiŻ, nr 49, 20.12.1989. 
Rozmowa Grażyny Wróblewskiej z dr. Ryszardem Bugajem, posłem na Sejm: „Czyim kosztem?”, KiŻ, nr 20, 15.05.1991.

Rozmowa Grażyny Wróblewskiej z prof. Januszem Szoslandem, prezesem Stowarzyszenia Włókienników Polskich: „Ministrowie odchodza - problemy pozostaja”, KiŻ, nr 36, 20.09.1989.

Rozmowa Iwony Konarskiej $z$ Barbara Labuda, przewodniczaca Parlamentarnego Koła Kobiet: „Czarownice w Sejmie”, KiŻ, nr 40, 2.10.1991.

Rozmowa Krystyny Kaszuby z Jolantą Plakiewicz: „Feminizm stowarzyszony", KiŻ, nr 45, 22.11.1989.

Rozmowa Janusza Miliszkiewicza z Andrzejem Micewskim: „Zawód: Polityk", KiŻ, nr 6, 5.02.1992.

Rozmowa Krystyny Kaszuby z Lidią Smyczyńska, redaktor naczelną "Tygodnika Demokratycznego": „Gdy jest się mała partia”, KiŻ, nr 18, 3.05.1989.

Rozmowa Krystyny Kaszuby $z$ wicemarszałkiem Sejmu dr Olgą Krzyżanowską: „Sytuacja tworzy polityka”, KiŻ, nr 50, 27.12.1989.

Rozmowa Marii Mankiewicz z Anną Popowicz: „Dywan z małych kawałków", KiŻ, nr 18, 1.05.1991.

Rozmowa Marii Mankiewicz z Grzegorzem Mędza, wicedyrektorem Departamentu Przekształceń Własnościowych Wielkich Przedsiębiorstw w Ministerstwie Przekształceń Własnościowych: „Chcesz mieć akcje...”, KiŻ, nr 29, 17.07.1991.

Rozmowa Natalii Iwaszkiewicz z Anną Popowicz, Pełnomocnikiem Rządu ds. Kobiet i Rodziny: „Czy demokracja jest rodzaju męskiego", KiŻ, nr 45, 6.11.1991.

Rozmowa Natalii Iwaszkiewicz $z$ Barbara Malak, rzecznikiem prasowym Komisji Krajowej NSZZ „Solidarność”, KiŻ, nr 33, 15.08.1990.

Rozmowa Natalii Iwaszkiewicz $\mathrm{z}$ posłem na Sejm dr. Marcinem Święcickim: „Weksel do wykupienia”, KiŻ, nr 32, 23.08.1989.

Rozmowa Olgi Oswald z Marią Mrówczyńską: „Sposoby na przedszkole", KiŻ, nr 18, 3.05.1989.

Rozmowa Renaty Marzewskiej z Renatą Grabską: „Kobieta wytrzyma więcej”, KiŻ, nr 5, 1.02.1989.

Rozmowa Teresy Gałczyńskiej z Ewą Osiatyńską: „Wernisaż dusz”, KiŻ, nr 2, 11.01.1989.

Rozmowa Wandy Bogusławskiej z Małgorzatą Bińkowską: „Pigułka czy spirala?”, KiŻ, nr 1, 4.01.1989, 17. 
Rozmowa Zofii Zubczewskiej z Ewą Łętowską: „Manowce równości”, KiŻ, nr 33, 7.08.1991.

\section{Wywiady w tygodniku „Przyjaciółka” (1989-1992)}

Rozmowa Aliny Czerskiej $z$ dr. Januszem Wojewódzkim, ginekologiem położnikiem: „To musisz wiedzieć”, Prz, nr 22, 31.05.1990.

Rozmowa Andrzeja Zarzeckiego z Andrzejem Kuzińskim, starszym specjalista w Departamencie Pomocy Społecznej Ministerstwa Pracy i Polityki Socjalnej: „Dziś o tym, kto otrzyma pomoc w opłatach za mieszkanie”, Prz, nr 32, 9.07.1990.

Rozmowa Andrzeja Zarzeckiego $z$ Danuta Demaniuk, podsekretarzem stanu w Ministerstwie Finansów: „Dziś o tym, czy nowy system podatkowy zagrozi naszym portfelom", Prz, nr 34, 22.08.1991.

Rozmowa Andrzeja Zarzeckiego z Jackiem Bukowskim, doradca ministra finansów, wicedyrektorem Biura Pełnomocnika Rządu ds. Przekształceń Własnościowych: „Dziś o prywatyzacji polskiej gospodarki”, Prz, nr 34, 23.08.1990.

Rozmowa Anny Marii Wiernik z mgr inż. Anną Michalczyk, naczelnikiem Wydziału Spraw Studenckich w Departamencie Nauki i Szkolnictwa Wyższego MEN: „Dziś o tym, czy warto studiować”, Prz, nr 21, 21.05.1992.

Rozmowa Anny Marii Wiernik z mgr Marią Mrówczyńska, dyrektorką Państwowego Przedszkola Ćwiczeń: „Dziś o tym, co robić, by przedszkola były tańsze”, Prz, nr 22, 31.05.1990.

Rozmowa Anny Sułkowskiej $z$ Anną Szymańską-Kwiatkowską: „2000 razy kobieta”, Prz, nr 41, 12.10.1989.

Rozmowa Elżbiety Banasiak $\mathrm{z}$ Andrzejem Dobrzyńskim: „Dziś o tym, dlaczego warto śledzić zmieniajace się prawo”, $\operatorname{Prz}, \mathrm{nr} 28$, 12.07.1990.

Rozmowa Elżbiety Banasiak z dr. Ryszardem Bugajem, posłem na Sejm, przewodniczącym Sejmowej Komisji Polityki Gospodarczej, Budżetu i Finansów, Prz, nr 27, 4.07.1991.

Rozmowa Elżbiety Banasiak z Gabrielem Janowskim, senatorem, przewodniczącym „Solidarności” Rolników Indywidualnych: „Dziś o kondycji rolników", Prz, nr 16, 18.04.1991.

Rozmowa Elżbiety Banasiak z Heleną Kowalską: „Dziś o tym, czego oczekuje pani Kowalska”, Prz, nr 52, 27.12.1990. 
Rozmowa Elżbiety Banasiak z Jerzym Stępniem, senatorem, generalnym komisarzem wyborów: „Dziś o wyborach do samorządu terytorialnego", Prz, nr 18, 3.05.1990.

Rozmowa Elżbiety Banasiak z Marią Sielicką-Gracka, posłanka OKP, współautorka projektu ustawy o ogródkach działkowych: „Dziś o obawach działkowiczów”, Prz, nr 39, 27.09.1990.

Rozmowa Elżbiety Banasiak z Wanda sokołowska, posłanką: „Remanent damskich spraw", Prz, nr 4, 24.01.1991.

Rozmowa Elżbiety Banasiak $z$ Wiesławą Ziółkowska, przewodniczaca Klubu Polskiej Unii Socjaldemokratycznej, członkinią Parlamentarnego Koła Kobiet: „Dziś o tym, dlaczego potrzebne jest kobiece lobby", Prz, nr 24, 13.06.1991.

Rozmowa Elżbiety Banasiak-Chmury z dr. Wojciechem Sadowskim, dyrektorem Ośrodka Pomocy Społecznej na warszawskim Mokotowie: „Dziś o tym, w czym może Ci pomóc opieka społeczna”, Prz, nr 28, 9.07.1992.

Rozmowa Elżbiety Szczurowskiej z Januszem Baranowskim, prezesem Spółdzielczego Zakładu Ubezpieczeń WESTA: „Dziś o kobietach", Prz, nr 10, 8.03.1990.

Rozmowa Elżbiety Szczurowskiej z Edwardem Wieczorkiem, dyrektorem Gabinetu Ministra Edukacji Narodowej: „Dziś o ustawie o systemie oświaty", Prz, nr 36, 5.09.1991.

Rozmowa Ewy Łuszczuk z ministrem Mieczysławem Wilczkiem: „To panie wybieraja!", Prz, nr 10, 9.03.1989.

Rozmowa Kaliny Dastych z Kazimierzem Olesiakiem, wicepremierem, ministrem rolnictwa, leśnictwa i gospodarki żywnościowej: „Z tej mąki będzie dobry chleb”, Prz, nr 19, 11.05.1989.

Rozmowa Mirosławy Grzeszak z Niną Simakowa: „Nie łatwo być uczona”, Prz, nr 23, 8.06.1989.

Rozmowa Ruty Pragier z Anną Kędzierską, Pełnomocnikiem Rządu ds. Kobiet: „Zmiany wymaga nie tylko fundusz alimentacyjny”, PrZ, nr 24, 15.06.1989.

Rozmowa Ruty Pragier z Aurelią Trzcińska, głównym specjalistą w Departamencie Pomocy Społecznej w Ministerstwie Pracy i Polityki Socjalnej: „Dziś o osłonie socjalnej z powodu wzrostu opłat za ogrzewanie, ciepłą wodę, elektryczność i gaz", Prz, nr 6, 6.02.1992.

Rozmowa Ruty Pragier $z$ doc. dr hab. Danuta Graniewską: „Dziś o bezrobociu wśród samotnych matek i ojców", Prz, nr 7, 13.02.1992. 
Rozmowa Ruty Pragier z Danuta Waniek, przewodnicząca Demokratycznej Unii Kobiet: „Dziś o tym, czy kobiety potrafia bronić swych praw", Prz, nr 15, 11.04.1991.

Rozmowa Ruty Pragier z doc. Danuta Markowska: „Dziś o tym, czy w Polsce potrzebna jest partia kobiet”, Prz, nr 13, 29.03.1990.

Rozmowa Ruty Pragier z Elżbietą Szemplińska, głównym specjalistą Ministerstwa Pracy i Polityki Socjalnej: „Co się zmieniło, a co nie w prawach pracownika”, Prz, nr 45, 8.11.1990.

Rozmowa Ruty Pragier z Elżbietą Szemplińską, głównym specjalistą Ministerstwa Pracy i Polityki Socjalnej: „Dziś o tym, na co należy zwracać uwagę w prywatnym zakładzie”, Prz, nr 49, 6.12.1990.

Rozmowa Ruty Pragier z Jerzym Krzekotowskim, naczelnikiem Wydziału Gospodarki Lokalowej w Ministerstwie Gospodarki Przestrzennej i Budownictwa: „Dziś o sprawach eksmisji w nowym prawie mieszkaniowym", Prz, nr 2, 9.01.1992.

Rozmowa Ruty Pragier z pracownikami Zakładów Mechanicznych im. Nowotki w Warszawie: Maria Niemczuk, Elżbieta Ramonotowska, Bogusławem Strzemiecznym, Wojciechem Sielużyckim: „Ile cierpliwości, ile nadziei?”, Prz, nr 31, 2.08.1990.

Rozmowa Ruty Pragier z Susan Vandiver, dyrektorem wykonawczym organizacji Służba na Rzecz Rodziny w Bostonie: „Zacząć od spraw najprostszych", Prz, nr 18, 3.05.1990.

Rozmowa Ruty Pragier z Zofią Kuratowska, wicemarszałkiem Senatu: „Dziś o służbie zdrowia i prawach kobiet”, Prz, nr 42, 7.11.1991.

Rozmowa Teresy Kaliny z prof. dr hab. Izabela Płaneta-Małecka, minister zdrowia i opieki społecznej: „Chcemy, aby pacjenci byli zadowoleni", Prz, nr 17, 27.04.1989.

Rozmowa Wiesławy Piątek z Anną Szymańska-Kwiatkowską: „Popieramy Annę Szymańską-Kwiatkowska”, Prz, nr 22, 4.06.1989.

Rozmowa Wiesławy Piątek z Aurelią Trzcińska, głównym specjalista w Departamencie Pomocy Społecznej Ministerstwa Pracy i Polityki Socjalnej: „Dziś o dopłatach do świadczeń za mieszkania", Prz, nr 32, 8.08.1991.

Rozmowa Wiesławy Piątek z Barbara Galas, kierownikiem działu pomocy środowiskowej w śródmiejskim Centrum Pomocy Społecznej w Warszawie: „Dziś o dopłatach do mieszkań”, Prz, nr 4, 24.01.1991.

Rozmowa Wiesławy Piątek $z$ dr. inż. Bolesławem Woźniakiem, prezesem Agencji Rynku Rolnego: „Dziś o tym, czy urodzaj będzie klęska”, PrZ, nr 33, 15.08.1991. 
Rozmowa Wiesławy Piątek $z$ dr. Jerzym Zdrzałka, podsekretarzem stanu w Ministerstwie Gospodarki Przestrzennej i Budownictwa: „Dziś o kredytach mieszkaniowych”, Prz, nr 11, 14.03.1991.

Rozmowa Wiesławy Piątek z Henryką Bochniarz, ministrem przemysłu i handlu: „Trzeba pomóc dobrym”, Prz, nr 42, 17.10.1991.

Rozmowa Wiesławy Piątek z Małgorzata Niepokulczycką: „Dziś o prawach klienta", Prz, nr 9, 28.02.1991.

Rozmowa Wiesławy Piątek z Piotrem Mrukiem, dyrektorem Departamentu Zatrudnienia w Ministerstwie Pracy i Polityki Socjalnej: „Dziś o nowym prawie dla bezrobotnych”, Prz, nr 39, 26.09.1991.

Rozmowa Wiesławy Piątek ze Stanisławem Chełstowskim, redaktorem naczelnym „Życia Gospodarczego": „Dziś o tym, jak się odnaleźć w trudnej rzeczywistości”, Prz, nr 24, 14.06.1990.

Rozmowa $z$ dr Aliną Włodarzowa, lekarką: „Profilaktyka przede wszystkim", Prz, nr 4, 24.01.1991.

Rozmowa Zdzisławy Jucewicz z Aurelia Trzcińską, głównym specjalista w Departamencie Pomocy Społecznej Ministerstwa Pracy i Polityki Socjalnej: „Dziś o dopłatach do mieszkań”, Prz, nr 43, 22.10.1992.

Rozmowa Zdzisławy Jucewicz z Marią Kaczor, główna specjalistka w Departamencie Prawnym Głównego Inspektoratu Pracy Państwowej Inspekcji Pracy: „Dziś o ochronie pracy kobiet”, Prz, nr 5, 30.01.1992.

Rozmowa Zdzisławy Jucewicz z sędzią Markiem Dobrowolskim: „Dziś o alimentach”, Prz, nr 13, 16.03.1992.

Rozmowa Zdzisławy Jucewicz z Tadeuszem Olejarzem, wicedyrektorem Departamentu Zatrudnienia w Ministerstwie Pracy i Polityki Socjalnej: „Dziś o tym, czego moga oczekiwać bezrobotni”, Prz, nr 49, 3.12.1992.

Rozmowa Zygmunta Włoczewskiego z Bartłomiejem Piotrowskim, podsekretarzem stanu w Ministerstwie Pracy i Polityki Socjalnej: „Dziś o możliwościach przekwalifikowania bezrobotnych”, Prz, nr 47, 21.11.1991.

Rozmowa Zygmunta Włoczewskiego z Hubertem Mikołajczykiem, głównym specjalistą w departamencie podatków i opłat Ministerstwa Finansów: „Dziś o tym, czy trzeba bać się powszechnego podatku dochodowego", Prz, nr 1, 2.01.1992.

Rozmowa Zygmunta Włoczewskiego z Małgorzata Kielską-Żukowską: "Chcemy się rządzić sami”, Prz, nr 16, 19.04.1990. 
Rozmowa Zygmunta Włoczewskiego z prof. Anną Przecławską: „Popieram filozofię Zagłoby", Prz, nr 14, 6.04.1989.

Rozmowa Zygmunta Włoczewskiego $z$ Włodzimierzem Jurkowskim, przewodniczącym oddziału warszawskiego Zrzeszenia Lokatorów: „Dziś o tym, jak pomagać lokatorom”, Prz, nr 46, 5.11.1990.

Rozmowa Zygmunta Włoczewskiego ze Zdzisławem Gryszką, naczelnikiem wydziału w departamencie polityki mieszkaniowej i gospodarki miejskiej w Ministerstwie Gospodarki Przestrzennej i Budownictwa: „Dziś o nowych zasadach finansowania budownictwa mieszkaniowego", Prz, nr 4, 23.01.1992.

\section{Opracowania}

Adams, Sally, Hicks, Wynford. Wywiad dziennikarski, tłum. Katarzyna Franek, (Kraków: Wydawnictwo UJ, 2007).

Bauer, Zbigniew. „Wywiad prasowy. Gatunek i metoda”, w: Zbigniew Bauer, Edward Chudziński (red.), Dziennikarstwo $i$ świat mediów, (Kraków: Universitas, 2004), 186-196.

Borkowski, Igor. „Współczesny prasowy wywiad dziennikarski: techniki prowadzenia, opracowanie, publikacja", Wrockawski Rocznik Historii Mówionej, nr 1, 2011, 57-79.

Daleszak-Wajdzik, Barbara. „Rozważania o wywiadzie prasowym”, Zeszyty Prasoznawcze, nr 1, 1974, 33-44.

Filas, Ryszard. „Zmiany w czytelnictwie prasy w Polsce 19891992 na tle przemian oferty prasowej", w: Alina Słomkowska (red.), Transformacja prasy polskiej (1989-1992), (Warszawa: Dom Wydawniczy Elipsa,1992), 27-41.

J.K. [Kołodziej, Jacek]. „Analiza zawartości mediów”, w: Walery Pisarek (red.), Słownik terminologii medialnej, (Kraków: Universitas, 2006), 6-8.

Kita, Małgorzata. „Wywiad jako gra. "Aktorzy“ wywiadu z perspektywy paratekstualnej”, w: Ewa Jędrzejko, Urszula Żydek-Bednarczuk (red.), Gry w języku i kulturze, (Warszawa: Energia, 1997).

Kita, Małgorzata. Wywiad prasowy. Język - gatunek - interakcja, (Katowice: Wydawnictwo Uniwersytetu Śląskiego, 1998).

Lewandowska, Izabela. „Wywiad jako technika zdobywania informacji źródłowych w badaniu historii najnowszej”, Echa Przeszłości, nr 5, 2004, 279-299. 
Lewandowski, Piotr. Creative writing publicystycznych tekstów dziennikarskich. Kreatywny wywiad dziennikarski, (e-bookowo. $\mathrm{pl}, 2005)$.

McQuail, Denis. Teoria komunikowania masowego, tłum. Marta Bucholc, Alina Szulżycka, (Warszawa: Wydawnictwo Naukowe PWN, 2008).

Szumlewicz, Piotr. „Ubóstwo kobiet w Polsce po 1989 roku”, Problemy Polityki Społecznej, nr 15, 2011, 65-82.

Pisarek, Walery. O mediach i języku, (Kraków: Universitas, 2007).

Ptaszek, Grzegorz. „Jak badać medialny obraz świata?”, w: Iwona Hofman, Danuta Kępa-Figura (red.), Współczesne media. Medialny obraz świata, t. 1: Zagadnienia teoretyczne, (Lublin: Wydawnictwo UMCS, 2015), 13-24.

Sobczak, Barbara. Wywiad telewizyjny na żywo. Charakterystyka gatunku, (Poznań: Wyd. „Poznańskie Studia Polonistyczne”, 2006).

Sokól, Zofia. „Transformacja czasopism kobiecych w Polsce (19891997)", Rocznik Historii Prasy Polskiej, t. 1, z. 1-2, 1998, 193201.

Szulczewski, Michał. „Informacja”, w: Bartłomiej Golka, Mieczysław Kafel, Zbigniew Mitzner (red.), Teoria i praktyka dziennikarstwa. Wybrane zagadnienia, (Warszawa: Państwowe Wydawnictwo Naukowe, 1964).

Ślawska, Magdalena. Formy dialogu w gatunkach prasowych, (Katowice: Wydawnictwo Uniwersytetu Śląskiego, 2014).

Wojtak, Maria. Gatunki prasowe, (Lublin: Wydawnictwo UMCS, 2004).

Wolny-Zmorzyński, Kazimierz, Kaliszewski, Andrzej, Furman, Wojciech. Gatunki dziennikarskie: teoria, praktyka, język, (Warszawa: Wydawnictwa Akademickie i Profesjonalne, 2009).

Wolny-Zmorzyński, Kazimierz, Kozieł, Andrzej. „Genologia dziennikarska”, Studia Medioznawcze, nr 3, 2013, 23-34. 